\title{
Immunochemistry of the Carbohydrate Antigens of Some Streptococcus salivarius Strains
}

\author{
By GUNVANTI C. KOTHARI, J. M. N. WILLERS \\ AND M. F. MICHEL* \\ Laboratory of Microbiology, State University, Catharijne-singel 59, \\ Utrecht, The Netherlands
}

(Accepted for publication 28 June I97I)

\begin{abstract}
SUMMARY
Extraction of Streptococcus salivarius NCTC 8606 with formamide yielded a mixture of carbohydrate antigens which was fractionated by alcohol precipitation into a type antigen (containing rhamnose, glucose, galactose) and a group-like (z) antigen. The type antigen is related to type antigen III in group F streptococci. After partial hydrolysis five disaccharides and two trisaccharides were isolated and identified. Five of these were inhibitory in the quantitative precipitation of the type antigen.

Two other strains of Streptococcus salivarius contained different group-like antigens and lacked the type antigen isolated from strain NCTC 8606.
\end{abstract}

\section{INTRODUCTION}

The oral streptococci designated as Streptococcus salivarius do not form a serologically homogeneous group, but are classified together because of their ability to form a levan when grown on sucrose agar (Williams, 1956).

Sherman, Niven \& Smiley (I943) distinguished two serological types. Willers, Ottens \& Michel (1964) described a strong cross-reaction between Streptococcus salivarius NCTC 8606 (type I of Sherman) and type III antigen of group F streptococci. This cross-reaction was probably due to the presence of a galactoside and a $\beta$-glucoside group in the determinants of both antigens. All investigated $S$. salivarius strains reacted in the capillary precipitin test with an anti-NCTC 8606 serum. Some strains contained an additional unrelated antigen, represented by strain ' $5 \mathrm{I}$ ' (Willers, Ottens \& Michel, 1964). Williams (I956) and Colman (I968) showed that a number of $S$. salivarius strains reacted with antisera to group K streptococci. Montague \& Knox (I968) found a reaction with group K antiserum only with extracts of $S$. salivarius type I strains.

Michel \& Krause (I967) and Willers \& Alderkamp (I967) have shown that a number of streptococci carry both a type antigen and a group-like (z) antigen. The fractionation of group and type antigens from purified formamide extracts is based on the higher solubility of group antigen in ethanol.

A second characteristic of streptococci carrying a type antigen is the excretion in the medium of a polysaccharide which is only reactive with anti-type serum and not with antigroup serum (Willers, Michel, Sijsma \& Winkler, 1964).

This paper describes the results of the alcohol fractionation of extracts of the two strains of Streptococcus salivarius which differed serologically and of strain Fw 86. Unlike the other

* Present address: Department of Clinical Microbiology, Medical Faculty, Rotterdam, The Netherlands. 6 
S. salivarius strains the latter strain does not contain galactose in the cell wall (Colman, 1968).

Partial acid hydrolysis of the purified serologically active polysaccharide of Streptococcus salivarius NCTC 8606 gave a number of oligosaccharides which were isolated. The probable structures were determined.

\section{METHODS}

Organisms and methods. Streptococcus salivarius strain NCTC 8606 was obtained from Dr C. A. de Moor, National Institute of Public Health, Utrecht, The Netherlands; S. salivarius strain 5I was isolated at the Laboratory of Microbiology, State University of Utrecht, The Netherlands (Willers, Ottens \& Michel, I964); S. salivarius strain FW 86 came from Dr G. Colman, Wright-Fleming Institute, London.

The culture conditions, the formamide extraction of bacteria, the purification of the crude formamide extracts and the fractionation of the antigens have been described earlier (Willers \& Alderkamp, I967).

The concentration and partial purification of polysaccharides excreted in the medium were performed as done by Willers, Michel et al. (1964).

Dilute $\mathrm{HCl}$ was used to extract serologically active material as described by Lancefield (1933).

Alternatively lyophilized bacteria ( $8.5 \mathrm{~g}$.) were extracted three times with $\mathrm{I} 50 \mathrm{ml}$. amounts of dimethyl-sulphoxide (DMSO) at $50^{\circ}$ for $\mathrm{I}$ h. (Gehring, 1967).

In one experiment the lyophilized bacteria were extracted repeatedly with an enzyme preparation from Streptomyces albus (McCarty, 1952). The acid-, the DMSO- and the enzyme-extracts were purified and fractionated in the same way as the formamide extracts.

Identification of sugars by paper chromatography. Paper chromatography was done as described by Willers, Michel et al. (1964) using solvent A: $n$-butanol: acetic acid: water (60: 10:20, by vol.); solvent B: $n$-butanol:pyridine:water (60:40:30, by vol.); and solvent C: $2 \cdot 4$ to $2 \cdot 5$ redistilled lutidine: water $(65: 35, \mathrm{v} / \mathrm{v})$.

Serological methods. The quantitative precipitin inhibition technique and the preparation of anti-NCTC 8606, anti-5I and anti-FW 86 sera were carried out as described by Willers et al. (1964), except that live bacteria were used for the preparation of antisera.

Analytical methods. Glucose was determined with glucose oxidase (Huggett \& Nixon, I957) and galactose with galactose oxidase (Roth, Segal \& Bertoli, 1965). Total hexosamines were estimated by the modified Elson \& Morgan method (Kabat \& Mayer, 196I). Rhamnose was estimated in unhydrolysed material using Gibbons' modification of the method of Dische \& Shettles (Kabat \& Mayer, I96r). Glucosamine and galactosamine determinations were kindly done by Dr J. A. F. Op den Kamp (Laboratory of Biochemistry, State University of Utrecht) by gas chromatography using a method described by Perry (1964) and modified by Op den Kamp \& van Deenen (1966). The borohydride reduction was done as described previously (Michel \& Willers, 1964). Optical rotation was measured in a Perkin Elmer I4I polarimeter. The rate of degradation of oligosaccharides in alkaline solution gives valuable information on the kind of glycosidic linkage of the oligosaccharides (Painter, 1963). Comparison of the results with the results obtained with disaccharides of known structure gives the probable linkage for the disaccharides. The modification for microquantities of Michel, van Vonno \& Krause (1969) was used.

Partial acid hydrolysis. The pure carbohydrate antigen $(6 \mathrm{~g}$.) was dissolved in $0 \cdot \mathrm{I} \mathrm{N}-\mathrm{HCl}$ to a concentration of $4 \mathrm{mg} . / \mathrm{ml}$. and heated at $100^{\circ}$ for $25 \mathrm{~min}$. After cooling to room temperature, the hydrolysate was neutralized with Dowex-I in the carbonate form, and filtered. 
The combined filtrates and washings were reduced on a flash evaporator to about $100 \mathrm{ml}$. The concentrated material was adsorbed onto a washed charcoal column (40 by $2.5 \mathrm{~cm}$.) containing $40 \mathrm{~g}$. Darco G6o and $40 \mathrm{~g}$. Celite 535 (Schiffman, Howe \& Kabat, 1958). In order to remove the monosaccharides the column was eluted with 31 . of distilled water. The column was further eluted with 3 l. each of $\mathrm{I}, 2,3,5$ and $7 \%$ ethanol. Each of the eluates was evaporated to dryness under reduced pressure and redissolved in $4 \mathrm{ml}$. distilled water. These eluates were processed by preparative paper chromatography on Whatman no. 3 MM using solvents A, B or C. Finally each single oligosaccharide was purified on a small charcoal + celite column ( 20 by $\mathrm{I} \cdot 5 \mathrm{~cm}$.).

\section{RESULTS}

After the final purification step the serological activity of the formamide extract of Streptococcus salivarius NCTC 8606 was only present in the water eluate of the DEAEcellulose column (Willers, Michel et al. 1964). The two materials precipitated by 4 vol. of

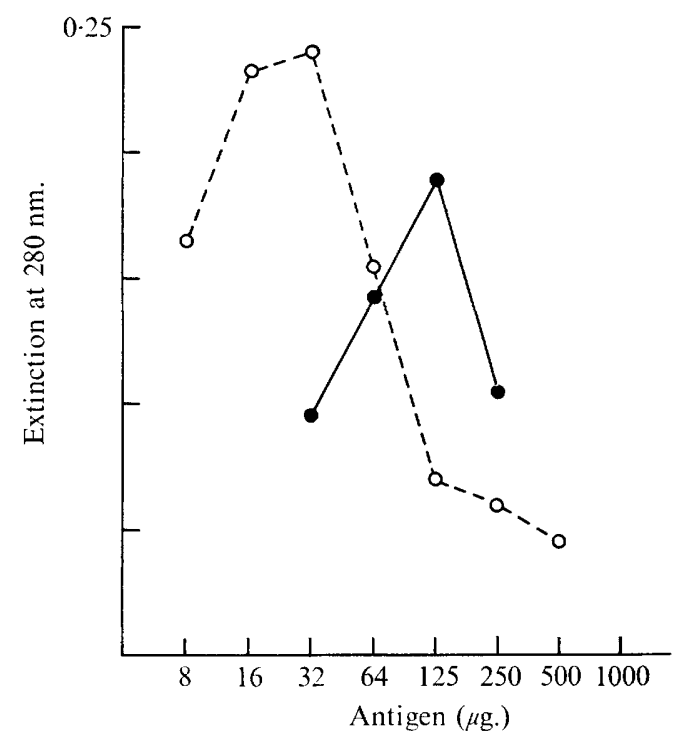

Fig. I. Quantitative precipitin reactions of fractions of a purified formamide extract of Streptococcus salivarius NCTC 8606, precipitated with 4 vol. alcohol (Falc) and 5 vol. acetone (Fac) with antiNCTC 8606 serum. O, Falc; 9 , Fac.

alcohol (Falc) and by 5 vol. of acetone (Fac) gave distinct peaks in the quantitative precipitin reactions as shown in Fig. I. Refractionation of Falc and Fac with increasing amounts of alcohol gave a separation in the serologically active fractions Falc ${ }_{1}$, Falc $_{2}$ and the serologically less active fractions $\mathrm{Fac}_{3}, \mathrm{Fac}_{5}, \mathrm{Fac}_{7}$. This was indicated by the increasing amounts of antigen and antiserum necessary to give the same amount of precipitate as measured in the quantitative precipitin reaction (Table I). Quantitative sugar analysis revealed that in the Falc fractions rhamnose, glucose and galactose were present in the ratio of about 2:6:7.

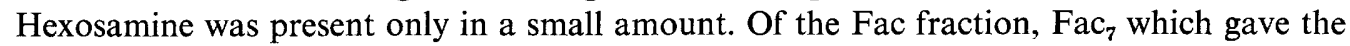
weakest reaction with anti-NCTC 8606 serum, was analysed. The relative amounts of rhamnose, glucose, galactose and hexosamine were $4: 3:$ I:2 (Table I).

Five hundred $\mu \mathrm{g}$. of the material isolated from the medium in which Streptococcus salivarius NCTC 8606 was grown showed the same serological activity as $8 \mu \mathrm{g}$. Falc ${ }_{1}$ material. 
The quantitative precipitin reactions of the different fractions of the formamide extracts of Streptococcus salivarius 5I showed that the most active fraction was precipitated with 6 vol. of alcohol. The fraction precipitable with I vol. of alcohol contained almost no polysaccharide. The $F_{2}$ and $F_{3}$ fractions were serologically less active (Table 2). Rhamnose, glucose, galactose and hexosamine in the $\mathrm{F}_{6}$ fraction were present in the ratio $5: 2: 1: 3$. Rhamnose, $N$-acetyl glucosamine and $\beta$-lactose (at $8 \mathrm{mg}$. $/ \mathrm{ml}$.) gave $27 \%$ inhibition of the quantitative precipitin reaction between $F_{6}$ and anti-5 $\mathrm{I}$ serum.

Formamide extracts of Streptococcus salivarius FW 86 did not contain any serological activity. The extraction of the bacteria with formamide at lower temperature (between $110^{\circ}$ and $140^{\circ}$ ) was, however, successful. Extractions with DMSO and Streptomyces albus

Table I. Serological activities and quantitative sugar analyses of different fractions of a formamide extract of Streptococcus salivarius NCTC 8606

\begin{tabular}{|c|c|c|c|c|c|c|c|c|}
\hline \multirow[b]{2}{*}{ Fraction* } & \multirow[b]{2}{*}{$\begin{array}{l}\text { Yield in } \\
\text { mg. }\end{array}$} & \multicolumn{2}{|c|}{$\begin{array}{l}\text { Quantitative precipitir } \\
\text { reaction } \dagger\end{array}$} & \multicolumn{5}{|c|}{ Quantitative sugar analysis ( $\mu \mathrm{g} . / \mathrm{mg}$.) } \\
\hline & & $\begin{array}{l}\text { Antigen } \\
(\mu \mathrm{g} .)\end{array}$ & $\begin{array}{c}\text { Serum } \\
\text { (ml.) }\end{array}$ & Rhamnose & Glucose & Galactose & $\begin{array}{l}\text { Hexo- } \\
\text { samine }\end{array}$ & Total \\
\hline Falc $_{1}$ & 1525 & 8 & 0.02 & 120 & 350 & 427 & 43 & 940 \\
\hline Falc $_{2}$ & I 125 & 8 & 0.02 & 152 & 443 & 553 & 54 & 1202 \\
\hline $\mathrm{Fac}_{3}$ & 186 & 32 & 0.08 & & & & & \\
\hline $\mathrm{Fac}_{5}$ & 445 & 125 & 0.08 & & & & & \\
\hline $\mathrm{Fac}_{7}$ & 75 & 250 & 0.2 & 470 & 390 & IIO & 210 & I 180 \\
\hline
\end{tabular}

* Subscript numerals indicate the vol. of alcohol and acetone used to reprecipitate the particular fraction.

$\dagger$ Extinction at $280 \mathrm{~nm}$. of the precipitate dissolved in $3 \mathrm{ml}$. of $0.02 \mathrm{~N}-\mathrm{NaOH}$ varied between $0 . \mathrm{I} 60$ and 0.230 at the peak of the precipitin curve.

Table 2. Serological activities and quantitative sugar analyses of the different fractions of the formamide extract of Streptococcus salivarius $5 \mathrm{I}$

\begin{tabular}{|c|c|c|c|c|c|c|c|}
\hline \multirow{3}{*}{$\begin{array}{l}\text { Antigen } \\
\text { fraction* }\end{array}$} & \multirow{3}{*}{$\begin{array}{l}\text { Yield in } \\
\text { mg. }\end{array}$} & \multicolumn{2}{|c|}{$\begin{array}{l}\text { Quantitative precipitin } \\
\text { reaction } \dagger\end{array}$} & \multirow{2}{*}{\multicolumn{4}{|c|}{ Quantitative sugar analyses in $\mu \mathrm{g} . / \mathrm{mg}$. }} \\
\hline & & & & & & & \\
\hline & & $(\mu \mathrm{g})$. & $(\mathrm{ml})$. & Rhamnose & Glucose & Galactose & Hexosamine \\
\hline $\mathrm{F}_{2}$ & 35 & 250 & $0 \cdot 1$ & 230 & 250 & 120 & 100 \\
\hline $\mathrm{F}_{3}$ & 55 & 250 & 0.12 & 440 & 210 & 90 & I 20 \\
\hline F 6 & 24 & 64 & 0.12 & 300 & 130 & 60 & 180 \\
\hline
\end{tabular}

Table 3. Serological activities and quantitative sugar analyses of formamide, DMSO and Streptomyces albus extracts of Streptococcus salivarius $\mathrm{FW} 86$, eluted from a DEAE-cellulose column with $0.0 \mathrm{I} 75 \mathrm{M}$-phosphate buffer $\left(\mathrm{pH}_{7}\right)$ and precipitable with 4 vol. of alcohol

Quantitative precipitin reaction $\dagger$

$\begin{array}{lcc}\begin{array}{l}\text { Extraction } \\ \text { procedure }\end{array} & \begin{array}{c}\text { Antigen } \\ (\mu \mathrm{gg})\end{array} & \begin{array}{c}\text { Antiserum } \\ (\mathrm{ml} .)\end{array} \\ \text { Formamide } & 4 & 0.025 \\ \text { DMSO } & 32 & 0.025 \\ \begin{array}{l}\text { Streptomyces } \\ \quad \text { albus } \text { enzyme }\end{array} & 16 & 0.025\end{array}$

Quantitative sugar analysis in $\mu \mathrm{g} . / \mathrm{mg}$.

$\begin{array}{cccc}\text { Rhamnose } & \text { Glucose } & \text { Galactose } & \text { Hexosamine } \\ \text { I } 80 & 75 & 0 & 14 \\ 30 & 50 & 0 & 28 \\ 70 & 60 & 0 & 14\end{array}$

+ See Table $\mathbf{~}$. 
enzyme were also performed. In the final purification step the water eluates of the DEAEcellulose column (Willers, Michel et al. 1964) were serologically inactive for all three extracts. The fractions eluted with 0.0I75 M-phosphate buffer $\left(\mathrm{pH}_{7}\right)$ consisted of material of high serological activity (Table 3). Quantitative analysis revealed that the buffer eluate of the formamide extract was serologically the most active fraction and contained a relatively high amount of rhamnose and almost no hexosamine. Glucose was the only hexose present. In the inhibition reaction none of the simple sugars tested gave important inhibition $(<20 \%)$. As the total amount of polysaccharides of the different fractions did not exceed $30 \%$, the presence of teichoic acids was suggested. The phosphate content was, however, less than $0.1 \%$ and in chromatograms no spots corresponding with either ribitol or glycerol could be detected.

(a)

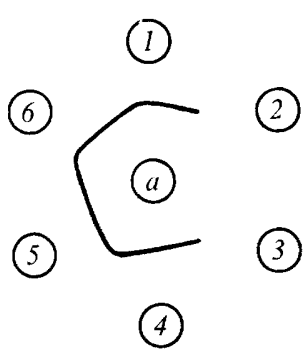

(b)

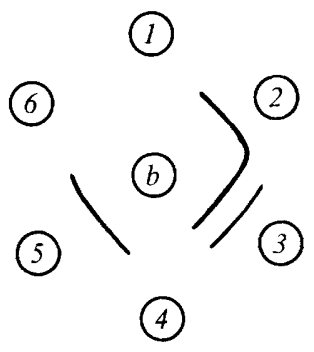

(c)

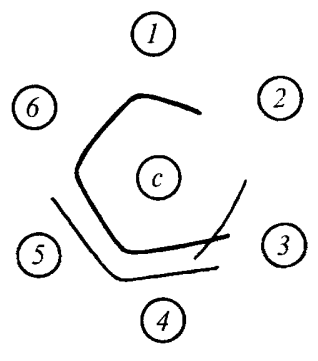

Fig. 2. Schematic representation of diffusion patterns in agar gel using antiserum against Streptococcus salivarius FW $86(a)$, NCTC $8606(b)$ and $5 \mathrm{I}(\mathrm{c})$. The formamide extract of NCTC 8606 precipitated with 2 vol. alcohol was used at a concentration of $0.5 \mathrm{mg}$. $/ \mathrm{ml}$. (2) and $5 \mathrm{mg} . / \mathrm{ml}$. (3). The other antigens were used at a concentration of $0.5 \mathrm{mg} . / \mathrm{ml}$.: formamide extract of $5 \mathrm{I}$, precipitated with 6 vol. alcohol (6); formamide extract of FW 86 (4), enzyme extract of FW 86 (5) and DMSo extract of FW 86 (1), all precipitated with 4 vol. alcohol.

Table 4. Properties of the oligosaccharides isolated from the type antigen Falc of Streptococcus salivarius NCTC 8606

\begin{tabular}{|c|c|c|c|c|c|c|}
\hline \multirow{2}{*}{$\begin{array}{c}\text { Code } \\
\text { designation }\end{array}$} & \multirow{2}{*}{$\begin{array}{l}\text { Percentage } \\
\text { alcohol in } \\
\text { elution fluid }\end{array}$} & \multicolumn{2}{|c|}{$R_{\mathrm{g}}$ on Whatman no. I } & \multirow{2}{*}{\multicolumn{2}{|c|}{$\overbrace{\text { Before } \mathrm{NaBH}_{4}}^{\text {Glucose: galactose ratio }}$}} & \multirow{2}{*}{$\begin{array}{l}\text { Optical } \\
\text { rotation }\end{array}$} \\
\hline & & Solvent A & Solvent B & & & \\
\hline B & I & 0.213 & 0.239 & $0: 2$ & $0: 1$ & $+I 4.0$ \\
\hline D & 2 & 0.267 & 0.342 & $\mathrm{I}: \mathrm{I}$ & I :O & $+13 \cdot 3$ \\
\hline $\mathrm{H}$ & 7 & 0.0875 & 0.119 & $\mathrm{I}: \mathrm{I}$ & I:0 & - \\
\hline$X$ & 2 & 0.396 & 0.509 & I : I & I :O & $+36 \cdot 5$ \\
\hline $\mathrm{Z}$ & 5 & 0.375 & 0.535 & I : I & I :O & +33.0 \\
\hline $\mathrm{E}$ & 5 & $0.07 \mathrm{I}$ & 0.084 & I : 2 & I : I & $\begin{array}{r}+47 \\
\end{array}$ \\
\hline$F$ & 5 & 0.071 & 0.0084 & $I: 2$ & $\mathrm{I}: \mathrm{I}$ & $+4 \cdot 2$ \\
\hline
\end{tabular}

The culture filtrates of streptococci $5 \mathrm{I}$ and FW 86 did not react with the homologous antisera.

The relationship between the Streptococcus salivarius antigens (NCTC 8606, 5I and FW 86) was studied by means of the agar gel diffusion test. Anti-Fw 86 gave a line of identity with the three different extracts of $\mathrm{FW} 86(0.5 \mathrm{mg}$. $/ \mathrm{ml}$.) and the $5 \mathrm{I}$ antigen $(0.5 \mathrm{mg} . / \mathrm{ml}$.). No precipitate was obtained with the NCTC 8606 antigen, even at concentrations up to $5 \mathrm{mg} . / \mathrm{ml}$. (Fig. $2 a$ ). The anti-5I serum gave a precipitation line with the three FW 86 extracts and the 


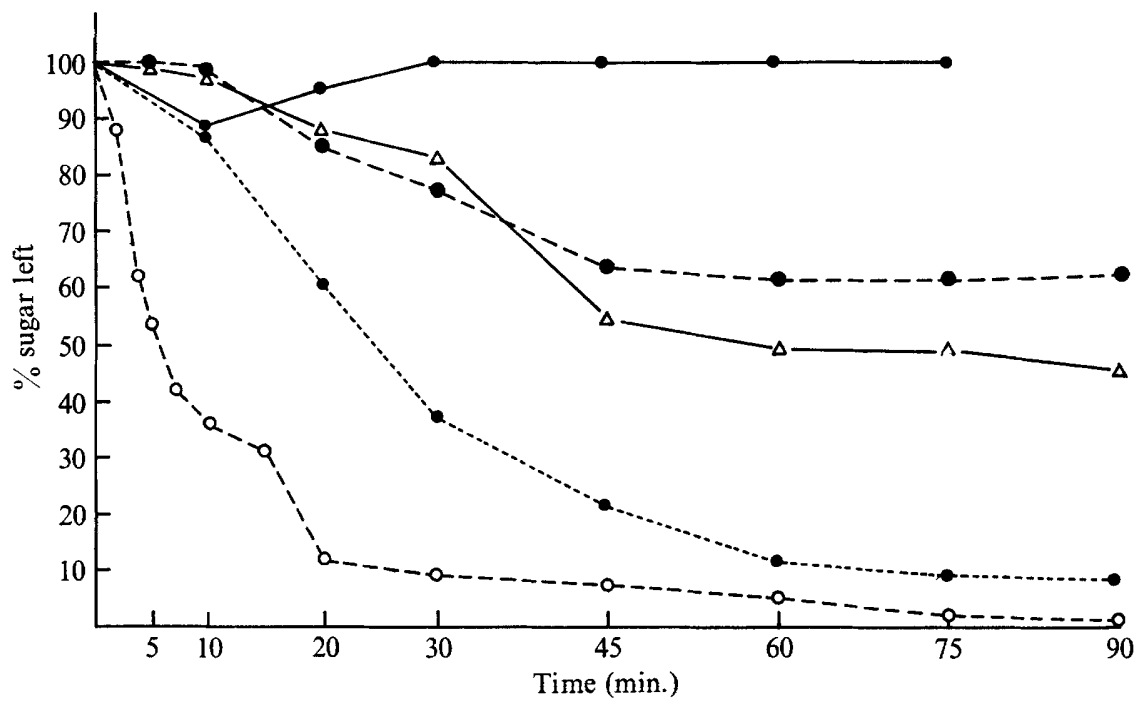

Fig. 3. Alkaline degradation of oligosaccharides isolated from partial acid hydrolysates of the Falc fraction of a purified formamide extract of Streptococcus salivarius NCTC 8606. -- - - - , oligosaccharide $\mathrm{X} ;-\cdots-\cdots$, oligosaccharide $\mathrm{Z} ;-\triangle \longrightarrow$, oligosaccharide $\mathrm{D} ;-\cdots---$, oligosaccharide $\mathrm{B} ;-\longrightarrow$, oligosaccharide $\mathrm{H}$.

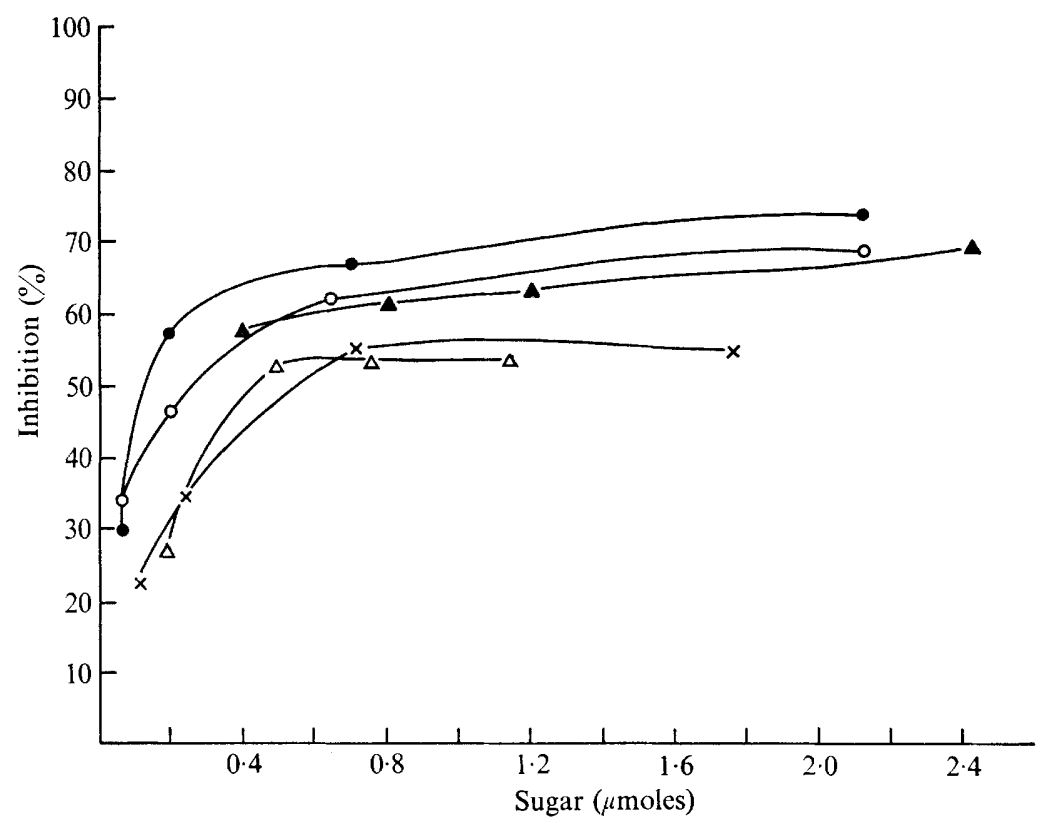

Fig. 4. Inhibition of the antigen-antibody reaction of the Falc NCTC 8606/anti-NCTC 8606 system by oligosaccharide $D(\triangle)$, oligosaccharide $B(x)$, oligosaccharide $H(\Delta)$, oligosaccharide $F(O)$, oligosaccharide $\mathrm{E}(\mathbf{\bullet})$. 
$5 \mathrm{I}$ antigen in concentrations of $0.5 \mathrm{mg}$. $/ \mathrm{ml}$, whereas the NCTC 8606 antigen reacted only at a concentration of $5 \mathrm{mg}$. $/ \mathrm{ml}$. (Fig. $2 b$ ). A second precipitation line was observed with the Fw 86 extracts prepared with formamide and Streptomyces albus enzyme. The anti-NCTC 8606 serum reacted only with the homologous extract and with the enzyme extract of $\mathrm{FW} 86$ (Fig. 2c).

Isolation and characterization of the oligosaccharides isolated from Streptococcus salivarius NCTC 8606 antigen. Partial acid hydrolysis yielded a series of oligosaccharides consisting of glucose and galactose (Table 4). The results of the alkaline degradation (Painter, I963) are given in Fig. 3. The borohydride reduction showed that all oligosaccharides had a galactose molecule at the reducing end. Not all of the oligosaccharides inhibited the precipitin reaction of NCTC 8606 antigen and anti-8606 serum (Fig. 4). Treatment of E and F with either $\alpha-$ or $\beta$-glucosidase or $\alpha$-galactosidase had no effect on their inhibitory activities while treatment with $\beta$-galactosidase decreased them by $50 \%$. Table 5 summarizes the most probable structures of these oligosaccharides and their inhibitory activity.

Table 5. Summary of the most probable structures of the isolated oligosaccharides and their serological activity

\begin{tabular}{|c|c|c|}
\hline $\begin{array}{c}\text { Code } \\
\text { designation }\end{array}$ & Most probable structure & $\begin{array}{l}\text { Amount of } \\
\text { sugar giving } \\
50 \% \text { inhibition } \\
\text { in the quanti- } \\
\text { tative precipi- } \\
\text { tin reaction } \\
\text { ( } \mu \text { moles) }\end{array}$ \\
\hline B & $O-\beta$-D-Galactopyranosyl $(\mathrm{I} \rightarrow 6)$-galactose & $0 \cdot 6$ \\
\hline D & $O$ - $\beta$-D-Glucopyranosyl (I $\rightarrow 6$ )-galactose & 0.4 \\
\hline $\mathbf{H}$ & $O$ - $\beta$-D-Glucopyranosyl $(\mathrm{I} \rightarrow 2)$-galactose & 0.2 \\
\hline $\mathrm{X}$ & $O$ - $\beta$-D-Glucopyranosyl $(\mathrm{I} \rightarrow 3$ )-galactose & 一 \\
\hline Z & $O-\beta$-D-Glucopyranosyl $(\mathrm{I} \rightarrow 4)$-galactose & - \\
\hline $\mathbf{E}$ & $O$-D-Galactopyranosyl (-glucopyranosyl-galactose) & 0.2 \\
\hline \multirow[t]{2}{*}{$\mathrm{F}$} & $O$-D-Galactopyranosyl (-glucopyranosyl-galactose) & 0.3 \\
\hline & Galactose & 40 \\
\hline
\end{tabular}

DISCUSSION

The fractionation of polysaccharide antigens based on differences in solubility in ethanol was used by Lancefield (1934) to separate group and type antigens in group B streptococci. This method was applied by Michel \& Krause (1967) and Willers \& Alderkamp (1967) to formamide extracts of streptococci carrying a type antigen of group F. Application of these techniques to the Streptococcus salivarius antigens revealed that a formamide extract of $S$. salivarius NCTC 8606 contained fractions which could be precipitated with I and 2 vol. of alcohol $\left(\mathrm{Falc}_{1}\right.$ and $\mathrm{Falc}_{2}$ ) and fractions which could only be precipitated with greater volumes of alcohol or acetone (Fac). The Falc $\mathrm{F}_{2}$ fraction was very pure as indicated by the recovery of the total amount of sugar after hydrolysis. Although the total carbohydrate content of the $\mathrm{Fac}_{7}$ fraction was about the same as that of the former fraction it was serologically far less active in the quantitative precipitin reaction with anti-NCTC 8606 serum. The $\mathrm{Fac}_{7}$ fraction contained more rhamnose and hexosamine, but less galactose than the Falc $_{2}$ fraction. The glucose contents were about the same. These data suggest that the formamide treatment of $S$. salivarius NCTC 8606 yields an extract which can be separated with alcohol into fractions comparable with type antigen of group F streptococci $\left(\right.$ Falc $_{1}$ and $\mathrm{Falc}_{2}$ ) and fractions comparable with group antigen (Fac). 
The serologically most active fraction of the formamide extract of Streptococcus salivarius $5 \mathrm{I}$ bacteria was precipitated with $6 \mathrm{vol}$. of alcohol. This suggests that the formamide extract of $S$. salivarius 5 I contains only a group antigen which is, however, different from Fac.

Formamide extraction of Streptococcus salivarius FW 86 at $160^{\circ}$ (Fuller, I938) gave no serologically active material. When, however, the extraction was performed at lower temperature serologically active material was obtained. The results were compared with DMSO and Streptomyces albus enzyme as extracting agents. In all three cases, upon purification, the active material could be eluted with phosphate buffer from the DEAE-cellulose column. The carbohydrate content of the formamide extract was only $27 \%$ and that of both other fractions even lower. These results suggest that destruction and removal of noncarbohydrate material was incomplete under the conditions used for extraction. The results of the quantitative precipitin reaction proved also that the material extracted with DMSO and enzyme had less activity than formamide extract. In all three kinds of extracts the serologically active material is precipitated with 4 vol. of alcohol. This is an indication of its being a group antigen. As already noted by Colman (I968) for cell wall material, no galactose could be found in the extracts of $S$. salivarius FW 86 .

From the culture filtrate of Streptococcus salivarius NCTC 8606 material could be isolated which was reactive with anti-NCTC 8606 serum, whereas the other two strains did not yield serologically active material. This is further support (Willers, Michel et al. 1964) for the presence of type antigen in Streptococcus salivarius NCTC 8606. The strains 5I and FW 86 contain only group antigens.

The serological differences between NCTC 8606, on one hand, and $5 \mathrm{I}$ and FW 86, on the other, are clear from the agar gel diffusion tests. There is a relationship between the group antigens of $5 \mathrm{I}$ and $\mathrm{FW} 86$, although the reactions with anti-5I serum reveal differences.

Further data on the structure of the determinant of the type antigen of NCTC 8606 (Falc) were obtained by partial acid hydrolysis and analysis of the isolated oligosaccharides. These oligosaccharides consisted only of glucose and galactose (Table 4). This is in accordance with the rather low relative amount of rhamnose in the Falc fraction. Although Montague \& Knox (1968) used different methods for the extraction of the type antigens, they isolated from type I antigen (NCTC 8606) two disaccharides $\left(\mathrm{D}_{2}\right.$ and $\mathrm{D}_{3}$ ) containing only glucose and galactose and one $\left(\mathrm{D}_{1}\right)$ consisting only of galactose. In all three cases galactose was at the reducing end. The only inhibitory sugar was $\mathrm{D}_{1}: O-\beta$-D-galactopyranosyl-( $\left.\mathrm{I} \rightarrow 6\right)$-D-galactose. This sugar is identical with our disaccharide $B . D_{2}$ and $D_{3}$ correspond with our $D$ and $\mathrm{X}$. In our experiments $\mathrm{D}$ proved to be inhibitory.

The disaccharide $\mathrm{H}$ had an inhibitory capacity equal to the trisaccharides $\mathrm{E}$ and $\mathrm{F}$. This suggests that $\mathrm{H}$ is not a part of these trisaccharides. As with none of the isolated oligosaccharides $70 \%$ inhibition can be exceeded, the possibility of a branched antigen was considered. In that case combinations of oligosaccharides might give considerably higher inhibitions than the individual components. None of the combinations of sugars in amounts giving individually $50 \%$ inhibition gave more than $70 \%$ inhibition. This value was also obtained by the addition of galactose to $\mathrm{E}$ or $\mathrm{F}$.

Willers, Ottens \& Michel (1964) and Montague \& Knox (1968) showed that galactose was the immunodominant hexose. Only disaccharide B contains galactose at the nonreducing end. But compound $\mathrm{B}$ has to be excluded as the terminal group of the determinant because its inhibitory activity is lower than that of $\mathrm{H}$ or the trisaccharides. From the data on the isolated oligosaccharides no definite conclusion can be drawn about the structure of the determinant group of the type antigen of Streptococcus salivarius NCTC 8606. 
The authors are indebted to Professor K. C. Winkler for constant advice; to Dr P. H. Batelaan, Laboratory for Organic Chemistry, State University Utrecht, for the use of the polarimeter; to $\mathrm{Mr}$ M. J. de Reuver for skilful assistance.

The work has been financially supported by the Netherlands Organization for the Advancement of Pure Research (Z.W.O.).

\section{REFERENCES}

Colman, G. (1968). The application of computers to the classification of streptococci. Journal of General Microbiology 50, I49-158.

Colman, G. \& Williams, R. E. O. (1965). The cell walls of streptococci. Journal of General Microbiology 4r, 375-387.

FUller, A. T. (1938). Formamide method for the extraction of polysaccharides from haemolytic streptococci. British Journal of Experimental Pathology 19, I30-139.

GeHRiNG, F. (1967). Dimethylsulfoxid als Extractionsmittel für Streptokokkenantigen. Nachweis im Immunodiffusionstest. Naturwissenschaften 54, 372.

Huggett, A. St G. \& Nixon, D. A. (1957). Use of glucose oxidase, peroxidase and $o$-dianisidine in determination of blood and urinary glucose. Lancet ii, $368-370$.

Kabat, E. A. \& MAYeR, M. M. (I96I). Experimental Immunochemistry. Springfield, Illinois: Charles C. Thomas.

LANCEFIELD, R. C. (1933). A serologic differentiation of human and other groups of hemolytic streptococci. Journal of Experimental Medicine 57, 57I-595.

LANCEFIELD, R. C. (1934). A serological differentiation of specific types of bovine hemolytic streptococci (group B). Journal of Experimental Medicine 59, 44I-458.

MCCARTY, M. (1952). The lysis of group A hemolytic streptococci by extracellular enzymes of Streptomyces albus. I. Production and fractionation of the lytic enzymes. Journal of Experimental Medicine 96, 555580.

Michel, M. F. \& Krause, R. M. (1967). Immunochemical studies on the group F streptococci, and the identification of a group-like carbohydrate in a type II strain with an undesignated group antigen. Journal of Experimental Medicine 125, 1075-1090.

Michel, M. F., van Vonno, J. \& Krause, R. M. (1969). Studies on the chemical structure and the antigenic determinant of type II antigen of group F streptococci. Journal of Immunology 102, 21 5-221.

MicheL, M. F. \& WiLLers, J. M. N. (1964). Immunochemistry of group F streptococci; isolation of groupspecific oligosaccharides. Journal of General Microbiology 37, 381-389.

Montague, E. A. \& KNOX, K. W. (I 968). Antigenic components of the cell wall of Streptococcus salivarius. Journal of General Microbiology 54, 237-246.

Op Den Kamp, J. A. F. \& van DeEnen, L. L. M. (I966). On the structure of glucosaminyl phosphatidyl glycerol of Bacillus megatherium. Chemistry and Physics of Lipids I, 86-89.

PAINTER, T. J. (1963). A colorimetric method for measuring the rate of degradation of disaccharides by alkali. Chemistry and Industry 36-37.

Perry, M. B. (I964). The separation, determination and characterization of 2-amino-2-deoxy-D-glucose (D-glucosamine) and 2-amino-2-deoxy-D-galactose (D-galactosamine) in biological materials by gasliquid partition chromatography. Canadian Journal of Biochemistry 42, 45I-460.

Roth, H., Segal, S. \& Bertoli, D. (1965). The quantitative determination of galactose, an enzymic method using galactose oxidase, with applications to blood and other biological fluids. Analytical Biochemistry 10, 32-52.

Schiffman, G., Howe, C. \& Kabat, E. A. (I958). Immunochemical studies on blood groups. XVI. Chromatographic examination of constituents split from blood group A, B and $\mathrm{O}(\mathrm{H})$ substances and from type XIV pneumococcal polysaccharides by Clostridium tertium enzymes. Journal of the American Chemical Society 8o, 6662-6670.

Sherman, J. M., Niven, C. F., Jun. \& Smiley, K. L. (1943). Streptococcus salivarius and other non-haemolytic streptococci of the human throat. Journal of Bacteriology, 45, 249-263.

Willers, J. M. N. \& Alderkamp, G. H. J. (1967). Loss of type antigen in a type III streptococcus and identification of the determinant disaccharide of the remaining antigen. Journal of General Microbiology 49, 4I-5I. 
Willers, J. M. N., Michel, M. F., SiJSMA, M. J. \& WinkLer, K. C. (I964). Chemical analysis and inhibition reactions of the group and type antigens of group F streptococci. Journal of General Microbiology 36, 95-ro5.

Willers, J. M. N., Ottens, H. \& Michel, M. F. (1964). Immunochemical relationship between Streptococcus MG, F III and Streptococcus salivarius. Journal of General Microbiology 37, 425-43I.

Williams, R. E. O. (1956). Streptococcus salivarius (vel hominis) and its relation to Lancefield group K. Journal of Pathology and Bacteriology 72, 15-25. 